\title{
Pengaruh Pemberian Jus Jambu Biji Merah (Psidium Guajava.L) Terhadap Kadar Hemoglobin dan Ferritin Serum Penderita Anemia Remaja Putri
}

\author{
Pagdya Haninda Nusantri Rusdi ${ }^{1}$, Fadil Oenzil ${ }^{2}$, Eva Chundrayetti ${ }^{3}$
}

\begin{abstract}
Abstrak
Anemia adalah kadar hemoglobin didalam sel darah merah dibawah kategori normal. Makanan yang tinggi zat besi dan yang dapat membantu proses penyerapan besi dapat meningkatkan kadar hemoglobin dan ferritin serum. Tujuan penelitian ini adalah menentukan pengaruh pemberian jus jambu biji merah (psidium guajava. L) terhadap kadar hemoglobin dan ferritin serum penderita anemia remaja putri. Penelitian ini dilaksanakan di Panti Asuhan Tri Murni Kota Padang Panjang. Desain penelitian adalah quasi eksperiment terhadap 34 orang remaja anemia yang dipilih secara simple random sampling. Subjek dibagi menjadi 2 kelompok, kelompok kontrol dan perlakuan. Kelompok perlakuan diberikan 100 gr jambu biji merah yang diolah menjadi jus selama 7 hari. Analisis data menggunakan uji $t$-dependent dengan derajat kemaknaan $\alpha=0,05$. Rerata kadar $\mathrm{Hb}$ pretest 10,26 gr/dl (kontrol) dan 10,50 gr/dl (intervensi), rerata kadar ferritin serum 33,63 $\mathrm{\mu g} / \mathrm{L}$ (kontrol) dan 36,63 $\mu \mathrm{g} / \mathrm{L}$ (intervensi). Rerata kadar Hb postest 10,98 gr/dl (kontrol) dan 12,48 gr/dl (intervensi), rerata kadar ferritin serum 40,35 $\mu \mathrm{g} / \mathrm{L}$ (kontrol) dan 57,40 $\mu \mathrm{g} / \mathrm{L}$ (intervensi). Hasil uji statistik didapatkan ada pengaruh pemberian jus jambu biji merah terhadap kadar hemoglobin dan ferritin serum penderita anemia remaja putri dengan nilai $p=<0,001$.
\end{abstract}

Kata kunci: anemia, hemoglobin, ferritin serum, jambu biji merah, remaja putri

\section{Abstract}

Anemia is hemoglobin levels in red blood cells under the normal category. The foods contain high iron and foods that can help the process of iron absorption is expected to increase the levels of hemoglobin and serum ferritin. The objective of this study was to determine the effect of red guava (Psidium guajava. L) juice on levels of hemoglobin and serum ferritin among adolescent girls with anemia. This research was conducted at the Orphanage Tri Murni Padang Panjang. The study design was quasy experiment. Simple random sampling method was used to select 34 adolescent girls with anemia. Subjects were divided into 2 groups, control and treatment. The treatment group was given 100 grams of guava which was processed into juice for 7 days. T-dependent test statistic with significance level $\alpha=0.05$ was used to analyzed the data. The result showed that the average hemoglobin of pre-test is 10,26 gr/dl (control) and 10,50 gr/dl (intervention), the average serum ferritin is 33,63 $\mu \mathrm{g} / \mathrm{L}$ (control) and 36,63 $\mathrm{g} / \mathrm{L}$ (intervention). The average hemoglobin of post-test is 10,98 gr/dl (control) and 12,48 gr/dl (intervention), the average serum ferritin $40,35 \mu \mathrm{g} / \mathrm{L}$ (control) and $57,40 \mu \mathrm{g} / \mathrm{L}$ (intervention). The result shown that there is an effect of treatment on levels of hemoglobin and serum ferritin among adolescent girls with anemia ( $p$ value $=<0.001)$.

Keywords: anemia, hemoglobin, serum ferritin, red guava, adolescent girls 
Affiliasi penulis: 1. Prodi Magister S2 Biomedik Fakultas Kedokteran Universitas Andalas (FK Unand), 2.Bagian Biokimia FK Unand, 3. Bagian Anak FK Unand.

Korespondensi: Pagdya haninda Nusantri Rusdi,

Email: pagdyahaninda@yahoo.co.id, Telp: 082284542265

\section{PENDAHULUAN}

Anemia adalah suatu keadaan sel darah merah (hemoglobin) atau protein pembawa oksigen didalam sel darah merah berada dibawah kategori normal. ${ }^{1}$ Keadaan ini sebagian besar disebabkan oleh faktor defisiensi zat besi yang ditandai dengan rendahnya kadar hemoglobin dan terjadinya penurunan kadar ferritin. Kadar hemoglobin normal pada laki-laki dan perempuan yaitu kadar hemoglobinnya lebih kurang 12 gr/dl, dikatakan anemia ringan jika kadar hemoglobinnya 10-12 gr/dl, anemia sedang 8-10 gr/dl dan anemia berat bila kadar hemoglobinnya kurang $8 \mathrm{gr} / \mathrm{dl}^{2}$

Ferritin adalah suatu protein yang menyimpan zat besi dan berperan penting dalam proses pembetukan hemoglobin dan sel darah merah. ${ }^{4}$ Kadar ferritin serum merupakan gambaran keadaan simpanan total zat besi didalam tubuh dan merupakan indikator cadangan besi yang bisa dilihat kadarnya melalui pemeriksaan laboratorium. ${ }^{5}$

Kadar ferritin untuk laki-laki yaitu 40-300 $\mu \mathrm{g} / \mathrm{L}$ dan untuk wanita 20-150 $\mu \mathrm{g} / \mathrm{L}$. Pemeriksaan kadar serum feritin terbukti sebagai indikator paling awal keadaan cadangan besi tubuh menurun. Pemeriksaan dapat dilakukan dengan menggunakan metode immunoradiometric assay (IRMA) dan enzyme linked immunosorbent assay (ELISA). ${ }^{6}$

Beberapa hasil penelitian tentang jus jambu bii merah menunjukkan bahwa terdapat perbedaan kadar hemoglobin pada kelompok yang mendapat suplementasi $\mathrm{Fe}$ dengan kelompok yang mendapat suplementasi $\mathrm{Fe}$ ditambah dengan mengkonsumsi jus jambu biji (100g jambu biji). ${ }^{7}$

Bagi anak-anak dan remaja putri khususnya yang menderita anemia dapat menyebabkan turunnya gairah belajar, konsentrasi, mengantuk serta dapat mengganggu pertumbuhan seperti tinggi dan berat badan yang tidak sempurna. Selain itu, juga menyebabkan turunnya daya tahan tubuh sehingga mudah terserang penyakit. ${ }^{2}$

Penyerapan zat besi sangat dipengaruhi oleh adanya vitamin C dalam tubuh remaja. Vitamin $\mathrm{C}$ dapat membantu mereduksi besi ferri $\left(\mathrm{Fe}^{3+}\right)$ menjadi ferro $\left(\mathrm{Fe}^{2+}\right)$ dalam usus halus sehingga mudah diabsorpsi tubuh, proses reduksi tersebut akan semakin besar jika $\mathrm{pH}$ didalam lambung semakin asam. Vitamin C dapat meningkatkan $\mathrm{pH}$ didalam lambung sehingga dapat meningkatkan proses penyerapan zat besi hingga 30\%. ${ }^{7}$

Kandungan vitamin $\mathrm{C}$ yang paling tinggi terdapat didalam buah jambu biji. Dalam bahasa latin jambu ini dikenal dengan sebutan Psidium guajava, dan dalam bahasa Inggris disebut Guava. Kandungan vitamin C dalam jambu biji lebih tinggi dari buah jeruk, dalam 100 gram buah jambu biji ini mengandung 183,5 mg vitamin C, sedangkan pada 100 gram buah jeruk terkandung 50-70 mg vitamin C. ${ }^{7}$ Penelitian ini bertujuan untuk melihat pengaruh jus jambu biji merah (Psidium guajava.L) terhadap kadar hemoglobin dan ferritin serum penderita anemia remaja putri.

\section{METODE}

Penelitian ini dilakukan di Panti Asuhan Tri Murni Kota Padang Panjang. Penelitian ini merupakan penelitian eksperimen dengan desain Pre-Test - Post-Test. Populasi pada penelitian ini adalah remaja putri Panti Asuhan Tri Murni Kota 
Padang Panjang, subjek penelitian adalah remaja yang memiliki kriteria inklusi; remaja yang menderita anemia ringan dan sedang dan bersedia menjadi responden. Jumlah sampel adalah 34 orang. Subjek dibagi menjadi 2 kelompok, terdiri dari kelompok kontrol dan kelompok perlakuan yang diberikan jus jambu biji merah, perlakuan diberi selama 7 hari berturutturut, hari pertama dilakukan Pre-Test dan pada hari ke 8 dilakukan Post-Test.

Pemeriksaan kadar hemoglobin menggunakan alat tes hemoglobin digital easy Touch $\mathrm{GCHb}$ dan Ferritin diukur menggunakan alat Immunochemiluminescent. Penelitian ini telah mendapatkan persetujuan etik dari Panitia Kode Etik Penelitian di Fakultas Kedokteran Universitas Andalas. Data hemoglobin dan ferritin yang diperoleh dianalisis dengan uji t-test ( $t$ dependent).

\section{HASIL}

Tabel 1. Rerata Kadar hemoglobin dan ferritin serum responden sebelum diberikan jus jambu biji merah (Psidium guajava. L) pada penderita anemia remaja putri

\begin{tabular}{cccc}
\hline Kelompok & $\mathbf{n}$ & $\begin{array}{c}\text { Rerata } \\
\mathbf{H b} \pm \text { SD } \\
(\mathbf{g r} / \mathbf{d l})\end{array}$ & $\begin{array}{c}\text { Rerata } \\
\text { Ferritin } \pm \text { SD } \\
(\boldsymbol{\mu g} / \mathbf{L})\end{array}$ \\
\hline Kontrol & 17 & $10,26 \pm 1,06$ & $33,63 \pm 6,15$ \\
& & & $36,63 \pm 8,09$ \\
\hline
\end{tabular}

Tabel 1 menunjukkan bahwa rerata kadar hemoglobin kelompok kontrol pretest adalah 10,26 gr/dl, dan rerata kadar ferritin serumnya adalah 33,63 $\mu \mathrm{g} / \mathrm{L}$. Sedangkan rerata kadar hemoglobin kelompok intervensi sebelum diberikan jus jambu biji merah (Psidium Guajava. L) adalah 10,50 $\mathrm{gr} / \mathrm{dl}$ dan rerata kadar ferritin serum kelompok kontrol (pretest) adalah 36,63 $\mu g / L$.
Tabel 2. Rerata kadar hemoglobin dan ferritin serum responden sesudah diberikan jus jambu biji merah (Psidium guajava. L) pada penderita anemia remaja putri

\begin{tabular}{|c|c|c|c|}
\hline Kelompok & $\mathbf{n}$ & $\begin{array}{c}\text { Rerata } \\
\text { Hb_SD } \\
\text { (gr/dl) }\end{array}$ & $\begin{array}{c}\text { Rerata } \\
\text { Ferritin } \pm S D \\
(\mu \mathrm{g} / \mathrm{L})\end{array}$ \\
\hline Kontrol & 17 & $10,98+0,99$ & $40,35+6,80$ \\
\hline Intervensi & 17 & $12,48+0,67$ & $57,40+14,09$ \\
\hline
\end{tabular}

Tabel 2 menunjukkan hasil rerata kadar hemoglobin kelompok kontrol postest adalah 10,98 gr/dl dan rerata kadar ferritin serumnya adalah 40,35 $\mu \mathrm{g} / \mathrm{L}$. Sedangkan rerata kadar hemoglobin kelompok intervensi sesudah diberikan Jus Jambu Biji Merah (Psidium Guajava. L) adalah 12,48 gr/dl dan rerata kadar ferritinnya adalah $57,40 \mu \mathrm{g} / \mathrm{L}$.

Tabel 3. Selisih nilai rerata kadar hemoglobin responden sebelum dan sesudah diberikan jus jambu biji merah (Psidium guajava. L) pada penderita anemia remaja putri

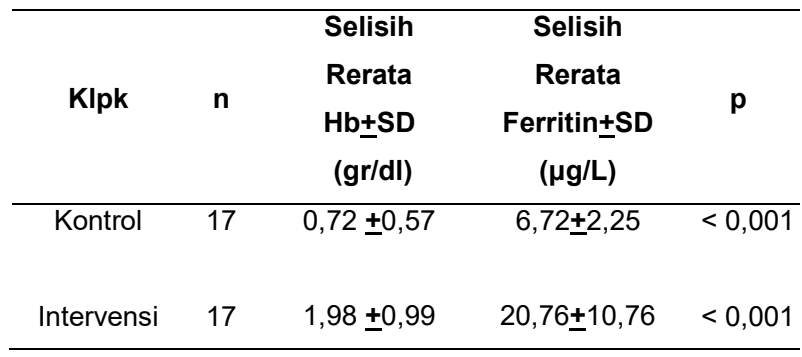

Tabel 3 menunjukkan bahwa antara pengukuran kadar hemoglobin dan ferritin serum pada kelompok kontrol dan intervensi didapatkan nilai $p<0,001$ maka dapat disimpulkan bahwa ada perbedaan yang signifikan antara kadar hemoglobin dan ferritin serum pengukuran pertama (pretest) dengan pengukuran kedua (postest). 


\section{PEMBAHASAN}

\section{Gambaran Rerata Kadar Hemoglobin dan Ferritin Serum Responden Sebelum dan Sesudah Diberikan Jus Jambu Biji Merah}

Hasil penelitian didapatkan rerata kadar hemoglobin kelompok kontrol pretest adalah 10,26 gr/dl dengan standar deviasi 1,06, dan rata-rata kadar ferritin serumnya adalah 33,63 $\mu \mathrm{g} / \mathrm{L}$ dengan standar deviasi 6,15. Sedangkan rerata kadar hemoglobin kelompok intervensi sebelum diberikan jus jambu biji merah (Psidium Guajava. L) adalah 10,50 gr/dl dengan standar deviasi 1,04, dan rerata kadar ferritin serumnya adalah 36,63 $\mu \mathrm{g} / \mathrm{L}$ dengan standar deviasi 8,09.

Rerata kadar hemoglobin kelompok kontrol (postest) adalah 10,98 gr/dl dengan standar deviasi 0,99 dan rerata kadar ferritinnya adalah 40,35 $\mathrm{\mu g} / \mathrm{L}$ dengan standar deviasi 6,80. Sedangkan rerata kadar hemoglobin kelompok intervensi sesudah diberikan Jus Jambu Biji Merah (Psidium Guajava. L) adalah 12,48 gr/dl dengan standar deviasi 0,67 dan rerata kadar ferritin serumnya adalah $57,40 \mu \mathrm{g} / \mathrm{L}$ dengan standar deviasinya adalah 14,09.

Seluruh sampel yang telah diperiksa didapatkan rerata kadar hemoglobinnya di bawah kategori normal, tergolong anemia ringan dan sedang. Rerata kadar ferritin serum tergolong normal. Akibat dari anemia, banyak remaja yang pucat, kurang semangat, mudah lelah, prestasi belajar menurun, sering mengantuk dan turunnya daya tahan tubuh.

Pada kelompok kontrol terjadi peningkatan rerata kadar hemoglobin dan ferritin serum. Namun kadar hemoglobinnya masih tergolong kepada anemia ringan. Beda halnya dengan kelompok intervensi yang diberikan jus jambu biji merah, terjadi peningkatan rerata kadar hemoglobin dan ferritin serum.

Kadar hemoglobin responden pada awal pemeriksaan dibawah kategori normal meningkat menjadi normal, sedangkan rerata kadar ferritin serumnya juga meningkat.

Jika anemia terjadi, pengobatan dilakukan dengan mengkonsumsi makanan yang kaya akan zat besi dan makanan yang dapat membantu proses penyerapan zat besi. ${ }^{3}$ Makanan yang banyak mengandung zat besi dari bahan makanan hewani seperti daging, ikan dan lain-lain. Bahan makanan yang dapat membantu proses penyerapan besi seperti sayur-sayuran dan buah-buahan yang banyak mengandung vitamin C seperti daun katuk, daun singkong, bayam, jambu biji, tomat, jeruk dan nanas. Penyerapan zat besi sangat dipengaruhi oleh adanya vitamin $\mathrm{C}$ dalam tubuh remaja karena vitamin $\mathrm{C}$ dapat membantu mereduksi besi ferri menjadi ferro didalam usus halus, sehingga mudah diserap oleh tubuh. Kandungan vitamin C tertinggi terdapat didalam buah jambu biji merah. $^{8}$

\section{Pengaruh Jus Jambu Biji Merah Terhadap} Kadar Hemoglobin dan Ferritin Serum

\section{Penderita Anemia Remaja Putri}

Berdasarkan uji t-test didapatkan nilai $p<$ 0,001 maka dapat bahwa ada perbedaan yang signifikan antara kadar hemoglobin dan ferritin serum sebelum dan sesudah diberikan jus jambu biji merah. Jadi dapat disimpulkan bahwa ada pengaruh pemberian jus jambu biji merah terhadap kadar hemoglobin dan ferritin serum penderita anemia remaja putri.

Pada hasil penelitian didapatkan hasil ferritin serum sebelum diberikan jus jambu biji masih tergolong normal, tetapi kadar hemoglobinnya menurun. Setelah diberikan jus jambu biji merah, kadar hemoglobin dan kadar ferritin serumnya juga meningkat. Pada dasarnya, penderita anemia defisiensi besi ditandai dengan kadar ferritin serum menurun dan diikuti dengan kadar hemoglobin menurun. 
Hal ini disimpulkan bahwa jambu biji merah tidak hanya meningkatkan hemoglobin dan ferritin serum pada penderita anemia defisiensi besi saja, tetapi juga mampu menigkatkan kadar hemoglobin dan ferritin serum penderita anemia lainnya.

Penelitian ini sejalan dengan hasil Yusnaini (2014) yang menyatakan bahwa ada perbedaan kadar hemoglobin pada kelompok yang mendapat suplementasi tablet $\mathrm{Fe}$ dengan kelompok yang mendapat suplementasi $\mathrm{Fe}$ dan mengkonsumsi jus jambu biji (100 gram jambu biji). ${ }^{7}$

Sama halnya dengan Ningtyastuti yang menyimpulkan bahwa ada pengaruh mengonsumsi jambu biji merah terhadap peningkatan kadar hemoglobin pada ibu hamil. ${ }^{9}$ Berdasarkan hasil penelitian yang dilakukan oleh Muhammad dan Sianipar yang menyimpulkan adanya hubungan anrtara asupan zat besi dengan kadar ferritin pada siswa sekolah dasar. ${ }^{5}$

Makanan yang kaya zat besi dan jus jambu biji merah dapat membantu proses penyerapan zat besi dan mampu mengobati penyakit anemia pada remaja putri. Zat besi yang terkandung dalam bahan makanan akan diserap dengan bantuan vitamin C. Vitamin C dapat membantu mereduksi besi ferri $\left(\mathrm{Fe}^{3+}\right)$ menjadi ferro $\left(\mathrm{Fe}^{2+}\right)$ dalam usus halus sehingga mudah diserap tubuh, proses reduksi tersebut akan semakin besar jika $\mathrm{pH}$ didalam lambung semakin asam. $^{10}$

Vitamin $\mathrm{C}$ dapat meningkatkan $\mathrm{pH}$ didalam lambung sehingga dapat meningkatkan proses penyerapan zat besi hingga $30 \%$. Vitamin C berperan memindahkan zat besi dari transferin yang ada didalam plasma ke ferritin hati. Sebagian besar transferin darah membawa zat besi ke sumsum tulang sebagai cadangan besi dan bagian tubuh lainnya. ${ }^{10}$
Pemberian jus jambu biji merah pada penelitian ini diberikan satu kali selama 7 hari berturut-turut, sehingga dengan waktu yang singkat tersebut belum terlihat kemampuan maksimal dari pemberian jus jambu biji merah dan pada penelitian ini juga tidak melihat faktor penghambat absopsi zat besi yang terkandung didalam bahan makanan seperti senyawa polifenol seperti tanin yang terjandung didalam teh.

\section{SIMPULAN}

Pemberian jus jambu biji merah dapat meningkatkan kadar hemoglobin dan ferritin serum pada penderita anemia remaja putri.

\section{DAFTAR PUSTAKA}

1. Kusumawardani E. Waspada penyakit darah mengintai anda. Yogyakarta: Hanggar Kreator; 2010.

2. Bakta IM. Hematologi klinik ringkas. Jakarta: EGC; 2006.

3. Arisman. Gizi dalam daur kehidupan. Buku Ajar IImu Gizi. Jakarta: EGC; 2010.

4. Sangelorang $\mathrm{Y}$, Kapantow NH, Malonda NSH. Hubungan antara asupan zat besi dengan kadar ferritin anak kelas 4 dan 5 sekolah dasar di Kelurahan Maasing Kecamatan Tuminting Kota Manado. Jurnal Fakultas Kesehatan Masyarakat Universitas Sam Ratulangi. 2013.

5. Andawari I, Alexander SIB, Joy MR. Hubungan antara asupan zat besi dengan kadar ferritin pada siswa kelas 4 dan 5 SD Katolik St. Theresia Malalayang Kota Manado. Jurnal Fakultas Kesehatan Masyarakat Universitas Sam Ratulangi. 2013;8.

6. Muhammad A, Sianipar O. Determination of iron deficiency in chronic disease anemia by 
the role of sTfR-F Index. Indonesian Journal of Clinical Pathology and Medical Laboratory. 2005;12(1):9-15.

7. Yusnaini. Pengaruh konsumsi jambu biji (Psidium Guajava.L) terhadap perubahan kadar hemoglobin pada ibu hamil anemia yang mendapat suplementasi tablet Fe (Studi kasus ibu hamil di wilayah kerja Puskesmas Kecamatan Indrapuri Kabupaten Aceh Besar Propinsi Aceh) (tesis). Semarang: Program Pascasarjana Universitas Diponegoro; 2014.

8. Almatsier S. Prinsip dasar ilmu gizi. Jakarta: Gramedia Pustaka Utama; 2003.hlm.160-252.
9. Ningtyastuti YE, Suryani E. Pengaruh mengkonsumsi jambu biji merah terhadap peningkatan kadar hemoglobin ibu hamil di Kelurahan Bandung Kecamatan Ngrampal Kabupaten Seragen (skripsi). Surakarta: Poltekes Surakarta.

10.Sambou CN, Yamlean PVY, Lolo WA. Uji efektivitas jus buah jambu biji merah (Psidium guajava, Linn) terhadap kadar hemoglobin (HB) darah tikus putih jantan galur wistar (Rattus norvergicus L.). Jurnal IImiah Farmasi - Unsrat. 2014;3(3):220-1. 